\title{
Baitul Maal Wat Tamwil as an Islamic Financial Inclusion Institution Model Towards a Sustainable Development
}

\author{
A. J. W. Mahri, S.A. Utami, Firmansyah, A. Cakhyaneu \\ Department of Islamic Economics and Finance \\ Universitas Pendidikan Indonesia \\ Bandung, Indonesia \\ ajajangwmahri@upi.edu
}

\begin{abstract}
This research is based on the issues of many informal sector businesses that do not have access towards capital from formal financial institutions, especially Islamic ones that are still considered to be excluded and hard to reach. The research aims to find the best model in empowering informal sector businesses based on sharia principles conducted by Baitul Maal Wat Tamwil (BMT), in which equivalent to the sharia micro finance institution. It adopted a qualitative descriptive approach and employed SWOT analysis of the ten BMTs which actively have given funding and empowered informal sector business in Bandung Raya. The model of empowerment implemented by BMT, is divided into three clusters with the following indicators such as: the utilization of productive economic, mentoring and training. The general results of this research indicate that the majority of BMTs is in the second cluster, with characteristic activities only productive economic empowerment through Islamic micro financing and still not contribute to the social function in running mentoring and training to informal sector businesses. Additionally, based on the results of the SWOT analysis, it is found that in general BMT has the potential to develop due to the principle of justice and its closeness to the micro business in which has not been accessed or touched by other financial institutions. On the other hand, the potential is still constrained by the inadequacy capacity of Human Resources in providing business advisory services at the same time. The implication of the research shows the urgent needs for competent human resources in developing BMTs members to be professional entrepreneurs who have good spirituality in empowering informal sector business community.
\end{abstract}

Keywords: Baitul Maal Wat Tamwil, Financial Inclusion, Empowerment, and Informal Sector

\section{INTRODUCTION}

Informal sector businesses have the potentials to develop their businesses if they supported by better financial sources. Based on the research results, the informal sector entrepreneurs have limited access to financial institutions due to strict administrative requirements (1).

This data can be seen in Figure 1 below:

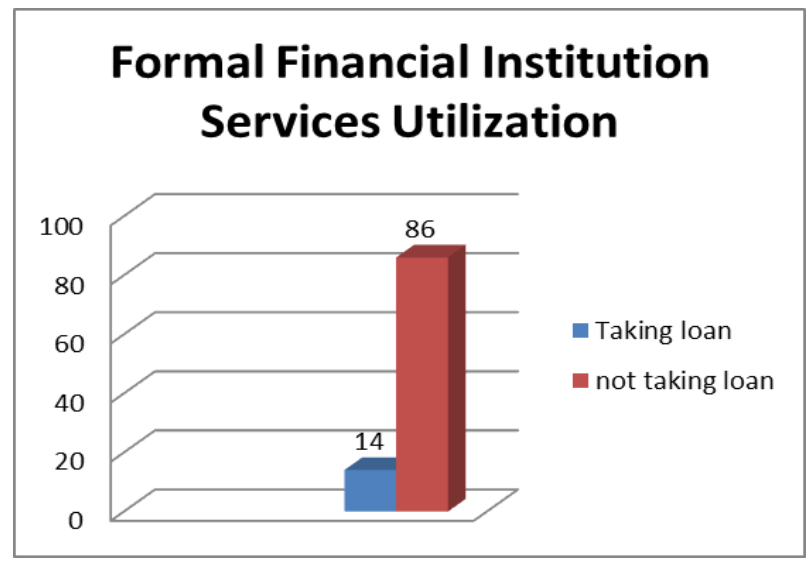

Fig. 1. Access of Informal Sector Entrepreneur to Formal Financial Institution

It is found that when asked about the Islamic financial knowledge, the majority of them do not know the answer and can only distinguish that Islamic financial one do not use the interest. These results are put into a material evaluation for the development of Islamic finance in general to notice Shariah compliance of products and services that can be provided for the benefit of the people entirely. In accordance with the study of (2), it is discovered that the efficiency or performance indicators of the success of Islamic banking is no longer shown by the ROA or ROE, but by the extent to which the institution of Islamic banking can reach out and give access to the public especially the marginalized economically. The informal sector businesses do not have collateral and come from poor communities. This is the general purpose of Islamic banking, but its implementation is often missing from the components Islamic Bank (3).

Some literature reviews and empirical studies mention that the financial system will contribute to the growth and development because it would channel between the owner of the funds with the funds. Due to this connection, increasing investment, employment opportunities will be created and ultimately drive the real sector (4). Thus, it becomes very important for the growing economy countries develop a financial system that can provide access to all levels of society and contribute positively in reducing the level of poverty and income inequality. This is the basic concept of financial inclusion. 
This paper aims to describe how the BMT as a model for Islamic Financial Institution Inclusion of social and economic function in the form of activities undertaken. In addition, this paper would like to reveal the potentials and problems faced by BMT internally and externally in the form of a SWOT analysis.

\section{LITERATURE REVIEW}

\section{A. Islamic Financial Inclusion}

The idea of financial inclusion in contemporary life comes from some theory of political economy, including the theory of modernization, investment theory, human capital theory and the theory of behavior. Basically, the fourth theory explains that the problem of poverty as a major problem in the construction due to the lack of capital invested. Therefore, according to this theory the poor should get the funds to be injected or capital to be invested. In addition, the poor must be given access to financial services in the form of micro credit that will boost productivity and opening of new jobs (5) (6).

The concept of Islamic finance related " Financial Inclusion " aims at two things, namely to promote risksharing contract as an alternative to debt-based financing in the conventional financial and the second, related to specific instruments used to redistribute wealth among the people. The use of risk-sharing contract in accordance with the principles of Islamic microfinance aimed at the micro, small and medium-sized businesses and micro-insurance to expand access to finance. In addition, the mechanism of redistribution of wealth carried out through instruments such as zakat, Sadaqah, Wakaf and Qardul Hasan to help the poor improving their socioeconomic capacity (4).

\section{B. Baitul Maal Wat Tamwil}

Baitul Maal Wat Tamwil (BMT) is an Islamic economic institution which are a modification of existing Baitul Maal during the period of the Prophet Muhammad. Unlike Baitul Maal, BMT is not merely having a social role as a non - profit institution, but also playing an important role in the commercial with the profit motive through economic functions. There are four activities undertaken by BMT (8), which collect and distribute zakat, infaq, shodaqoh and wakaf, financing activities, financing and services. In financing activities, BMT is generally employed wadiah and mudharabah agreement. For financing activities mudharabah and musharakah are used while the activity in BMT services using kafalah, Ijarah, Hiwalah, wakalah and Rahn contract.

In regards to(9), BMT main characteristics are:

- $\quad$ Providing services to the poorest people and lift them to be actively involved in the economy

- Creating a sustainable microfinance and not dependent on donations which provide micro finance

- $\quad$ increase the accountability of institutions reported as zakat and other Islamic charity and as Islamic micro finance institutions

- Creating a sustainable microfinance with low failure rate and reduce the level of bad debts, when the micro-credit given to members who have the skills or expertise in generating revenues
- As an institution that is able to overcome problems in the community by presenting the goals and values simultaneously.

Thus, the Baitul Maal Wat Tamwil based on the characteristics of Islamic financial institutions that have the potential to give very wide access to people, especially people who have had limited access to finance at a formal financial institution. This concept is intended that the BMT as an Islamic Financial Institution that contribute socially and economically to empower communities.

\section{The Concept of Economic Development and Inclusion in Islam}

Development concept in Islam has three dimensions, namely the development of individual or human as themselves, physical development and social development of society (10). In Islam, the happiness of a person's life can not only be achieved by increasing revenue, but also by building a three-dimensional person in them. At the same time, economic capacity building in Islam gives the meaning that humans can obtain materially satisfaction by eliminating various forms of barriers to gain spiritual elevation (11).

Economic institutions play an important role in operationalizing the goal in achieving social justice that will distribute the rule in Islam. Islam aims to distribute resources between rich and poor to achieve a balance. In essence, the wealth belongs to Allah for the welfare of the entire universe, therefore, to avoid a gap between rich and poor, Islam has rules not to do excessive spending (israf), show exaggerated-luxuries while it suggests a simple living. On the other hand, Islam also pays attention to the poor who cannot attain work due to a wide range of reasons to get relief from income which is owned by the rich. Thus, the rights of private (property) do not mean exclusive, but inclusive, because the rights of the poor can be redeemed by the income of the rich. This will create a balance of economic and sustainable development without a high disparity between the rich and poor (4).

\section{METHODOLOGY}

Research methodology of this research used a qualitative descriptive approach to determine how the Baitul Maal Wat Tamwil (BMT) has been engaged in social and economic function in society. Qualitative analysis is conducted by using the model of Research \& Development (R \& D). According to (12) method of research and development is the research methods used to produce a particular product, and to test the effectiveness of it. To be able to produce specific products, research analysis is needed (survey or qualitative methods are used) as well to test the effectiveness of these products in order to function well in society at large. For this purpose, it is necessary to study to test the effectiveness product (used in experimental method). Which then, the test is used in a study on how to develop sharia-based model of financial inclusion through the mechanism of research and development to produce the best model and effective in improving the welfare of informal sector businesses.

The necessary data in this study were collected through direct observation in the field, i.e. To visit the BMTs in the city of Bandung and its surroundings, using in-depth interviews (depth interview) with the managers of BMT 
and members of BMT, and distribute the questionnaire to members of BMT which is an informal sector business. In addition, to identify the various problems faced by BMT, SWOT analysis (Strength, Weakness, Opportunities and Threat) was performed.

The population in this research was all BMT in Bandung Raya. The sampling technique used purposive sampling, namely choosing BMT that will be the object of research based on the amount of assets and a member of the most active participation in providing financing to informal sector businesses. Based on this parameters 10 BMTs selected as the object of research, namely: BMT Itqan (IT); BMT Baituraahim (BM); BMT Mitra Sadaya (MS); BMT Dana Ukhuwah (DU); BMT Barrah (BR); BMT Dinar Cipta Madani (DM); BMT Daarut Tauhid (DT); BMT Nurul Ummah (NU); BMT Mitass (MT) and BMT El Dana Manfaat (EL). Then the necessary data in this research collected through direct observation in the field, i.e. A visit to the BMT in Bandung and surrounding region through the conclusion depth interviews (depth interview) with the managers of BMT.

Research Design:

1. Work Activities

- Preliminary Studies

Author conducted preliminary studies in the first year of the study and the results show an overview of informal sector entrepreneurial in Bandung. Afterwards, observation of Shariabased model of financial inclusion that is characterized by financing products provided by BMT.

- Developing instruments (questionnaires) and interviews to determine the model of financial inclusion which is owned by BMT.

- Designing Validation

2. Achieve Results

\section{- $\quad$ The Resulting Product}

The resulting product of this research is described of sharia-based owned by BMT, R \& D model by analyzing the opportunities and challenges of financial inclusion models owned by BMT and by demonstrating the impact of the BMT model against the economic capacity of informal sector entrepreneur.

- Development of financial inclusion shariabased models owned by BMT which affect the economic capacity of informal sector entrepreneur

- Product

R \& D Model Financial Inclusion sharia-based owned by BMT

\section{FINDING AND DISCUSSION}

\section{A. Description of Function Activity of Baitul Maal Wat Tamwil}

Based on descriptive research on the activities carried out ten BMTs as the research objects, functionally, not all of them optimally carry out their activities in terms of economic and social function. There are four BMTs have run activities and functions optimally, namely BMT Itqan, BMT Mitra Sadaya, BMT Barrah and BMT Daarut Tauhid. Activities that have been performed by the four BMTs including collection and distribution of funds of Zakat, Infaq, Shodaqoh and Wakaf (ZISWAF), financing or loans with a free - interest loan (Qardhul Hasan) for the poor, training and assistance to small businesses that obtain financing (social function). In addition to that, the economic function being operated includes funding activities, financial and service activities are patterned on profits.

Six out of ten BMTs as an object of research, namely BMT Baiturrahim, BMT Dana Ukhuwah, BMT Dinar Cipta Madani, BMT Nurul Ummah, BMT Mitrass and BMT El Dana Manfaat have yet not fully run the activities of BMT according to the function. There are several background reasons, among them are still in their early stages of development so that the management system developed in modest with the value of assets and human resources numbers/ capabilities are limited, so they have not been able to carry out the activities undertaken in accordance with the function of BMT. In general, a function that has not run optimally, namely social function, including ZISWAF fund management. There is an interesting fact that people are more accustomed to channel funds to the specific ZISWAF institution's management to perform these functions, such as BAZ or Zakat Management Organization. Therefore, those developing BMTs have not been able to raise funds ZISWAF optimally. In addition, fundraising ZISWAF by BMT is limited due to the ability of its members in channeling ZISWAF funds. On the other hand it is perceived by the members of the small community that BMT is generally bridging informal businesses, so the ability to channel its ZISWAF funds are still limited.

Other activities, namely financing agreement Qardhul Hasan or free-interest loan is still rare to be carried out by BMT, in which the given loan, has not meant to be given any results/profit or any enhancement. This contract is imposed on the poor people who need urgent or emergency funds for education and other needs. Furthermore, the activity of which has not run optimally by BMT are the activity assistance and training to members of the BMT. In fact, this activity is considered important because apart from being the responsibility of BMT in empowering the community, training and mentoring are also used as one of the strategies for BMT to grow and develop in line with the increased economic capacity of its members.

Based on the results of interviews with the managers of BMT whose assets and a large number of members, such as BMT Itqan showing that their assets can grow quickly. It is mainly caused by its capacity building with its members and assistance of its members who run microenterprises, either as merchants or small farmers to succeed in business. In addition, they also give a briefing 
spiritual or religious knowledge with the expectations of their members to religious observance, the better. As a result, when the BMT with foster resilient members in running their business, then members can also develop economically and have a higher loyalty to BMT as well a good spirituality and implications towards the better behavior.

The BMT have not able to run training programs and mentoring due to Human Resources (HR) limitation in terms of number and competence. This situation becomes the barriers for them to provide training and business mentoring regularly. That is why HR is limited only to provide financing and reassemble the return of members on a regular basis. Another main problem faced by BMT managers is difficult to find employees who are willing to work at low wages despite quite tiring and time consuming work especially the need to go directly to the community.

Based on the research of descriptive associated with the activities carried out by the BMT's in the city of Bandung and its surroundings, then a classification or grouping the BMT's is made into three clusters, with the following conditions: Cluster I (BMT which only carrying out its activities on the social dimension), cluster II (BMT only which run its activities in economic dimension), and cluster III (BMT which carrying out its activities on the social and economic dimensions simultaneously). With this, the ten BMTs who becomes the object of the research, none of any BMT included in cluster I, six BMTs included in cluster II (Baiturrahim, Dinar Cipta Madani, Nurul Ummah, Dana Ukhuwahm Mitrass, El Dana Manfaat) and four BMT (Itqan, Mitra Sadaya, Barrah and Daarut Tauhid) included in Cluster III.

\section{B. SWOT Analysis Baitul Maal Wat Tamwil}

In assessing the potential and the problems encountered, the following described force (Strength), weakness (Weakness), opportunities (Opportunity) and challenges (Threat) at BMT based on field studies in Table 1 .

TABLE I. ANALYSIS, SWOT BAITUL MAAL WAT TAMWIL

\begin{tabular}{|c|c|}
\hline Strength & Weakness \\
\hline $\begin{array}{l}\text { Loyalty } \\
\text { members } \\
\text { Strategic } \\
\text { location } \\
\text { Methods of } \\
\text { marketing " } \\
\text { proactive " } \\
\text { (Service Pick } \\
\text { Up) } \\
\text { Uphold the } \\
\text { sense of kinship } \\
\text { Having a variety } \\
\text { of products that } \\
\text { can be offered } \\
\text { Conduct } \\
\text { training and } \\
\text { assistance to } \\
\text { micro } \\
\text { businesses }\end{array}$ & 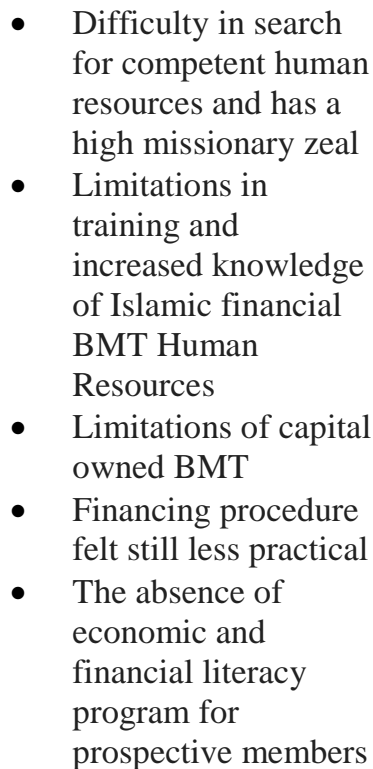 \\
\hline
\end{tabular}

\begin{tabular}{|c|c|}
\hline 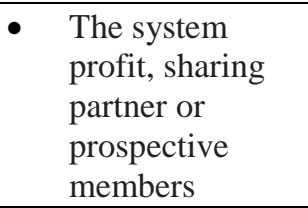 & $\begin{array}{l}\text { of Islamic } \\
\text { - Infrastructure BMT } \\
\text { is still modest, so } \\
\text { make members } \\
\text { uncomfortable }\end{array}$ \\
\hline Opportunity & Threat \\
\hline $\begin{array}{ll}\text { - } & \text { Islamic society } \\
\text { Environment } \\
\text { A lot of } \\
\text { informal sector } \\
\text { businesses } \\
\text { - } \quad \text { Public access to } \\
\text { Islamic financial } \\
\text { institutions is } \\
\text { still limited } \\
\text { The cooperation } \\
\text { with Islamic } \\
\text { banks in the } \\
\text { form of " } \\
\text { Linkage } \\
\text { Program" }\end{array}$ & $\begin{array}{l}\text { - The establishment of } \\
\text { a bank nearby BMT. } \\
\text { The number of loan } \\
\text { sharks surrounding } \\
\text { community is } \\
\text { considered to be } \\
\text { more practical in the } \\
\text { financing operation } \\
\text { - Wrong interpretation } \\
\text { of the BMT function, } \\
\text { which is considered } \\
\text { simply as a social } \\
\text { institution that does } \\
\text { not pay attention to } \\
\text { the value of profit. }\end{array}$ \\
\hline
\end{tabular}

Several strategies are being made to develop the strength of BMT from within and potential BMT from outside, such as literacy of Islamic finance and economics, socialization and promotion of BMT, building a network of cooperation with Islamic banks and universities, improving the quality of human resources, actively involved in the organization of associations BMT, commitment in providing training and mentoring to members. Socialization and literacy of Islamic economics and finance into the first part is important because BMT as Islamic financial institutions must introduce the first basic concept is, to all parties' pliers involved in the BMT, so in the end there will be no interpretation misunderstood any measures BMT performed. In addition, a more mainstream of Economics and Islamic finance literation is done so that the parties involved in BMT can keep Shariah Compliance of the BMT.

At a later stage, the necessary dissemination and promotion of BMT to the strategic community groups, such as housewives through Ta'lim Assembly group, the small businesses (traders) and teachers. This needs to be done to make them more familiar with the concept of BMT and advantages compared to other financial institutions. The network of cooperation with the Islamic Bank performed to obtain supporting funds in increasing the capacity of capital owned by BMT. It is very possible to do because Islamic banks have an interest in channeling funds to the community, but in real practice, it becomes too risky and high cost when Islamic banks should channel funds directly in small quantities to the community grass root level. Therefore, today, many programs are carried out by the Islamic Bank to provide supporting funds to BMT

Other forms of cooperation that need to be carried out by BMT is with universities, especially universities organizers of Economic and Islamic Finance study programs. It is given that the majority of BMT still has problems with the availability of competent human resources and has a high missionary zeal in developing the BMT. Among the Program is to be executed by the college 
is an opportunity for students to do an internship at the same devotion in BMT, make a cooperate with employees/new employee recruitment and engage employees into training BMT organized by universities or bring academician to provide training and guidance to employees, administrators and members of the BMT.

In addition, active involvement with the organization, association of BMT has also become a necessity. This is to determine any regulatory developments, voicing opinions on fixing regulations or rules BMT, and to conduct a comparative research to other BMTs that have been successful as an input for improving the performance of BMT. The last strategy is very important to note is owned by a BMT commitment to coaching/mentoring and advising the members in developing their economic capacity. This activity is considered still too difficult for most BMT, whereas if BMT able to do this, then goodness will have a major impact on the development and advancement of BMT it. The logic is very simple, when members of the BMT empowered economically through a mentoring process, then the members of BMT will have better economic conditions. ultimately the loyalty of the members can be built which is good for better BMT.

Thus, BMT as Islamic financial institutions can operate inclusively, could be a solution of various problems of development in Indonesia and the world at large. BMT as an institution that focuses on community empowerment program for small and medium-sized groups through the roles and functions carried out by BMT scheme itself. BMT plays an important role in reducing poverty and it appears to the activities undertaken, namely social activities (Baitul Maal) and economic activity (atTamwil) (14).

\section{CONCLUSION}

BMT is the Islamic financial institutions that perform the function of social and economic. However, in its real implementation, there are some BMTs have not been able to carry out both functions. There are several underlying reasons, including limitation of capital, human resources and the ability to understand the functions and programs that can be run by BMT. Therefore, the dimension of the activities that can be carried out by BMT covered only the narrow scope and perceived has not been practically effective. Such conditions can be described in the SWOT analysis, in assessing the potential and constraints faced by BMT both internally and externally. Therefore, we need some strategies to do, ranging from the basic foundation that must be built in setting up BMT as Islamic financial institutions, namely an understanding of the concept of Islamic economics and finance for all parties involved in the BMT until the formation of networks of cooperation with various institutions will support the development of BMT performance. This being the case, is expected BMT able to prove that as an Islamic financial institution, BMT could be a solution to the problems of development and become an important part of the realization of sustainable development.

\section{REFERENCES}

[1] A. Jajang W, Mahri et.al. (2014) Model Financial Inclusion Berbasis Syariah. Penelitian Tahun pertama Hibah Penelitian UPI Bidang PPKBK

[2] Choudhury MA. Financial Globalization and Islamic Financing Institutions: the Topic Revisited. Islam Econ Stud. 2001;9(1).

[3] Abdul Rahman AR. Islamic Microfinance: A Missing Component in Islamic Banking. Kyoto Bull Islam Area Stud [Internet]. 2007;12:38-53. Available from: http://www.microfinancegateway.org/gm/document1.9.50560/Islamic Microfinance.pdf

[4] Mohieldin M, Iqbal Z, Rostom A, Fu X. The Role of Islamic Finance in Enhancing Financial Inclusion in Organization of Islamic Cooperation (OIC) Countries. Islam Econ Stud [Internet]. 2012;20(2):55-120. Available from: http://elibrary.worldbank.org/doi/pdf/10.1596/1813-9450-5920

[5] Bhanot D, Bapat V, Bera S. Studying financial inclusion in northeast India. Int J Bank Mark [Internet]. 2012;30(6):465-84. Available

from: 10.1108/02652321211262221 \nhttp://search.ebscohost.com/login.a spx?direct=true $\& \mathrm{db}=\mathrm{bth} \& \mathrm{AN}=79723657 \&$ site $=$ ehost-live

[6] Karpowicz I. Financial Inclusion, Growth and Inequality: A Model Application to Colombia. IMF Work Pap. 2014;(WP/14/166):1-31.

[7] Hamzah Z. Analysis Problem of Baitul Maal Wat Tamwil ( BMT ) Operation in Pekanbaru Indonesia Using Analytical Network Process ( ANP ) Approach. 2013;3(8):215-28.

[8] Wahibur Rohman. (2013). Baitul Maal Wat Tamwil and Poverty Empowerment. Qudus International Journal Of Islamic Studies. Volume 1 | Number 2 | July-December 201

[9] Bin Mislan Cokro Hadisumarto W, Ghafar B. Ismail A. Improving the effectiveness of Islamic micro-financing. Humanomics [Internet]. 2010;26(1):65-75. Available from: http://www.emeraldinsight.com/doi/abs/10.1108/08288661011025 002

[10] Mirakhor A. Islam and the Path to Human and Economic Development. 2010;1-4. Available from: Retrieved from http://www.palgraveconnect.com/pc/doifinder/10.1057/978023011 0014

[11] Chapra, M. U. (1981). Islam and Economic Development : A Strategy for Development With Justice and Stability, 162.

[12] Creswell JW. Research design Qualitative quantitative and mixed methods approaches. Res Des Qual Quant Mix methods approaches. 2003;3-26.

[13] Sakai M, Marijan K. Mendayagunakan Pembiayaan Mikro Islami. 2008:17. Available from: http://www.smeru.or.id/report/training/menjembatani_penelitian_d an_kebijakan/untuk_organisasi_advokasi/files/73.pdf

[14] Yuniar GN. Development of MSMEs ( Micro, Small and Medium Enterprises ) by Baitul Maal Wat Tamwil ( BMT ) as an Instrument for Poverty Reduction. 2015;3(2):41-4 